\title{
18. AUTOCHTHONOUS AND ALLOCHTHONOUS QUATERNARY OSTRACODA FROM SITE 893, SANTA BARBARA BASIN'
}

\author{
Robin Whatley ${ }^{2}$ and Ian Boomer ${ }^{2}$
}

\section{INTRODUCTION}

Site 893 of Ocean Drilling Program (ODP) Leg $146\left(34^{\circ} 17.25^{\prime} \mathrm{N}\right.$, $\left.120^{\circ} 02.2^{\prime} \mathrm{W}\right)$ was drilled in a $576-\mathrm{m}$ water depth. Recovered from the site was an extensive marine sequence of late Quaternary sediments from the Santa Barbara Basin. The benthonic Ostracoda from 29 core-catcher samples recovered from the 200-m-thick sequence have been analyzed for assemblage composition and population structure. Our studies show that this sequence contains a mixed assemblage of allochthonous taxa together with some autochthonous deep-water taxa. The shallow-water taxa are considered to have been transported down-slope into the basin.

Few of the taxa recorded in the present study have been identified to species level because of the high number of juveniles recovered that render detailed taxonomy difficult. However, the presence of species which possess well-developed ocular structures (e.g., Ambostracon tweedsmuirensis and Cytheromorpha krausei) clearly indicates an origin within the photic zone and attests to the allochthoneity of part of these assemblages. We believe that the absence of adult specimens in many of the taxa recorded shows that the juveniles of both shelf and upper bathyal taxa have been transported downslope. Only Cytheropteron sp. A and Loxoconchidea dolgoiensis Brouwers, 1990, have been recovered with well-represented suites of instars, indicating autochthoneity.

A number of previous studies have described Oligocene to Pleistocene deep-water Ostracoda from onshore exposed sections in southern California (Cronin, et al., 1983; Finger, 1983, 1982; LeRoy, 1943), some of which are related to the assemblages at Site 893.

\section{ENVIRONMENTAL SETTING}

The paleoceanographic regime that existed in the Santa Barbara Basin during the Quaternary has been outlined for ODP Site 893 (Shore-based Scientific Party, 1994). The great thickness of Quaternary sediment clearly indicates a high sedimentation rate. The sequence consists of two distinct types of deposition: (1) welllaminated, fine-grained sediments (thought to have been deposited under low-oxygen bottom-water conditions), and (2) more massive, well-mixed sediments (thought to have been deposited under welloxygenated conditions). Throughout the sequence, thin, sand-grade beds are thought to be the result of turbidity currents.

The sequence (Table 1) shows no large-scale sedimentological variation, and only one lithological unit was identified, although it was divided into six subunits (Shore-based Scientific Party, 1994).

Kennett, J.P., Baldauf. J.G., and Lyle, M. (Eds.), 1995. Proc: ODP. Sci. Results. 146 (Pt. 2): College Station. TX (Ocean Drilling Program).

Institute of Earth Studies, University of Wales, Aberystwyth, Dyfed. SY23 3DB, United Kingdom.
Table 1. Lithological summary of the Quaternary sequence at ODP Site 893. Ages are based on the pollen and planktonic foraminifer records (after Kennett, Baldauf, et al., 1994).

\begin{tabular}{|c|c|c|}
\hline Lithological subunit & $\begin{array}{l}\text { Depth } \\
\text { (mbsf) }\end{array}$ & Age \\
\hline $\begin{array}{l}\mathrm{IA}=\text { Upper laminated } \\
\text { sequence }\end{array}$ & $0-24.25$ & Holocene to latest Pleistocene \\
\hline $\begin{array}{l}\text { IB = Úpper nonlaminated } \\
\text { sequence }\end{array}$ & $24.25-37.0$ & late Pleistocene \\
\hline $\begin{array}{l}\text { IC = Upper intermittently } \\
\text { laminated sequence }\end{array}$ & $37.0-131.0$ & late Pleistocene \\
\hline $\begin{array}{l}\text { ID = Lower laminated } \\
\text { sequẹce }\end{array}$ & $131.0-145.5$ & late Pleistocene \\
\hline $\begin{array}{l}\mathrm{IE}=\text { Lower nonlaminated } \\
\text { sequence }\end{array}$ & $145.5-160.5$ & late Pleistocene \\
\hline $\begin{array}{l}\mathrm{IF}=\text { Lower intermittently } \\
\text { laminated sequence }\end{array}$ & $160.5-196.5$ & late Pleistocene \\
\hline
\end{tabular}

\section{FAUNAL ANALYSES}

The 29 samples investigated were processed using the methods outlined by Boomer and Whatley (in press). Ostracoda, as with all other Crustacea, grow by a series of (up to eight) incremental stages or moults through the process of ecdysis. As a result, each individual sheds a suite of discrete carapaces during its life cycle, each one larger than its predecessor. Thus, in a quiet environment, one may expect to recover an almost complete series of moulted valves. Because of the complexities of the taphonomic process and fragility of the smallest valves, this is rarely the case. Increasing energy levels, formed by current action, tend to remove valves of increasing size (Whatley, 1983a, 1983b, 1988; Brouwers, 1988).

Fossil assemblages reflect such sorting, and we can use this technique to identify the effects of high- and low-energy post-mortem transport and sorting. These studies must take into account the size of different adults (since juveniles of one species may be larger than adults of another) and the preservation potential of thick-shelled forms vs. more delicate species.

Whatley (1983a, 1983b, 1988) outlined the use of such ostracod population studies to identify the presence of transported ostracod assemblages. Brouwers (1988) has successfully applied this technique to studies of sub-fossil Ostracoda in transported sediments from the Alaskan continental shelf.

Very few of the species recovered in the present study are assigned to previously described taxa. Initial faunal comparisons were made with studies of shallow-water ostracod assemblages from the western coast of Central and North America. None of those studies (Benson, 1959; Benson and Kaesler, 1963; Carreño, 1992; Swain, 1969; Swain and Gilby, 1974) appeared to have taxa in common with the present work. The greatest faunal similarities are with the sublittoral to upper bathyal ( $\sim 20-350 \mathrm{~m}$ in depth), late Quaternary to Recent assemblages of Ostracoda described by Brouwers (1990, 1993) from the Gulf of Alaska. Brouwers identified five depth-related os- 

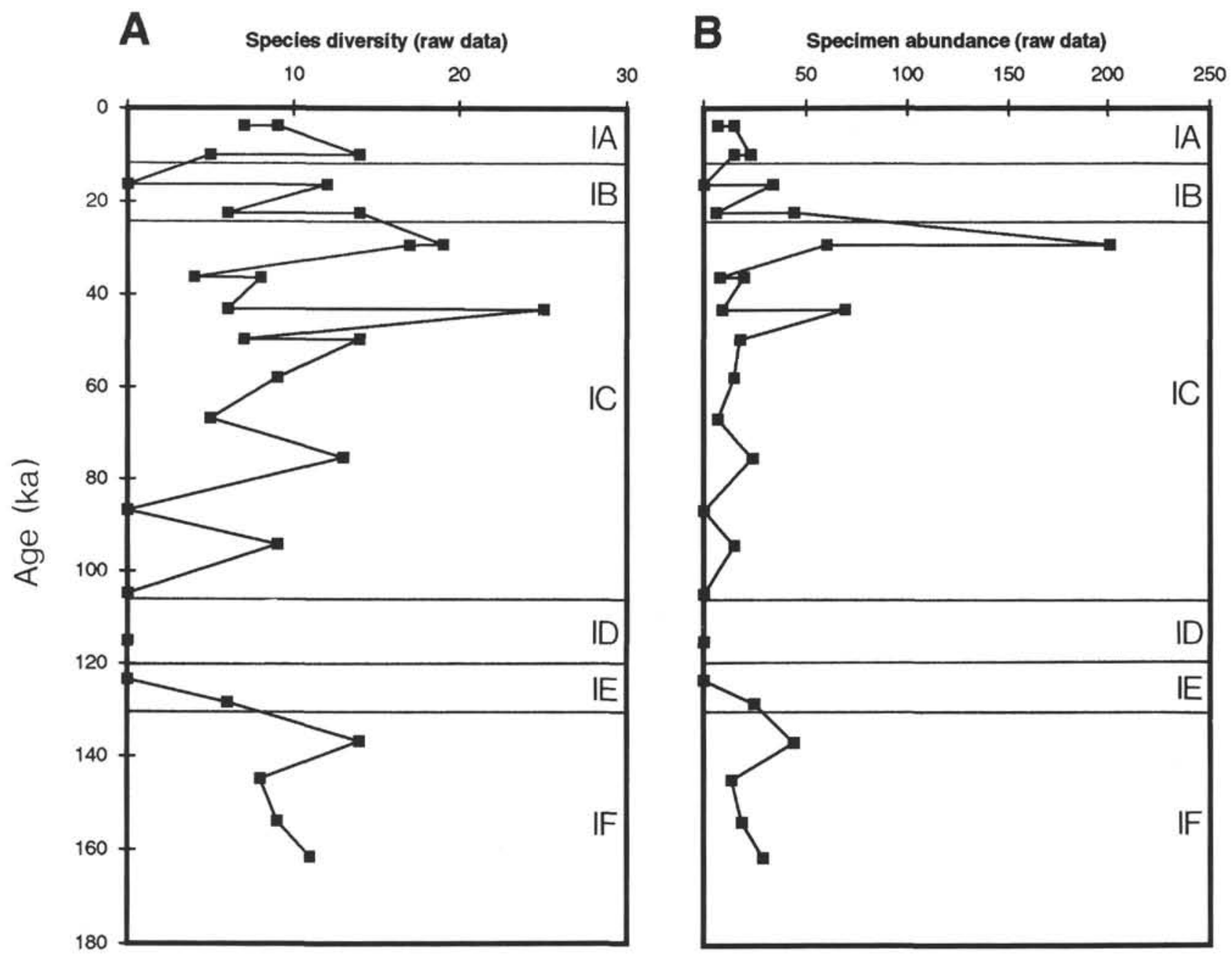

Figure 1. A. Simple species diversity (number of species recorded in each sample). B. Specimen abundance (total number of valves in a 50 -cm ${ }^{3}$ sample), plotted against age in thousands of years BP. Labels $1 \mathrm{~A}$ to IF refer to the lithological subunits detailed in Table 1.

tracod assemblages across the continental shelf of that region. At least four of the taxa described by Brouwers are recorded in the present study. Those taxa, together with their depth range in the Alaskan study, are listed below.

Loxoconchidea dolgoiensis Brouwers, 1993: mid-shelf to upper bathyal;

Loxoconcha russellensis Brouwers, 1993: inner to mid-shelf;

Cytheromorpha krausei Brouwers, 1993: inner to outer shelf; and

Cluthia foresteri Brouwers, 1990: mid-shelf to upper bathyal.

The presence of these taxa in deeper waters off California may indicate a downslope habitat shift towards the equator, thereby maintaining a similar temperature range. However, such a hypothesis can only be applied to in situ assemblages.

A taxonomic review of the Cytheruridae from the Gulf of Alaska has not yet been published, but it is expected that it would indicate similar faunal connections with the Santa Barbara Basin. The presence of the above taxa at Site 893 may indicate that the Alaskan fauna is distributed along a broad stretch of the western American continental shelf. However, the presence of these more northern species in the Quaternary sediments of Site 893 may result from a latitudinal shift in their distribution in response to cooler, possibly glacial intervals.

Because of the taxonomic difficulties in working with such a high proportion of juvenile valves, no biostratigraphical assessment has been attempted. Furthermore, the apparently high degree of allochthoneity in the assemblages would complicate biostratigraphical interpretations.

No typical deep-sea, bathyal assemblages were recovered from Hole $893 \mathrm{~A}$. Those species that are deemed in situ are considered to be sublittoral taxa at their lower depth range. The specimen abundance (number of valves per $50 \mathrm{~cm}^{3}$ sample) and the simple specific diversity (number of species recorded) are represented in Figure 1. These data are then smoothed, using a five-point moving mean, to give the data represented in Figure 2.

Species diversity is highly correlated with specimen abundance in any fossil sample. This is an effect of sampling and can be demonstrated using a rarefaction curve. Low abundance samples are likely to underrepresent the original population structure, and ideally one should consider a sample of at least 100 specimens before statistically significant conclusions can be drawn. Given the small sample size available for Deep Sea Drilling Project and ODP studies, this effect strongly influences our results.

Only one sample yielded a large fauna (Sample 146-893A-5HCC. $16-18 \mathrm{~cm} ; 201$ valves), and that was dominated $(57 \%)$ by one species, Loxoconchidea dolgoiensis Brouwers, 1993. Most other samples yielded less than 50 specimens. Diversity was generally between seven and fifteen species.

We can see from Figures 1 and 2 that diversity and abundance are positively correlated so that we can draw some conclusions, this low- 

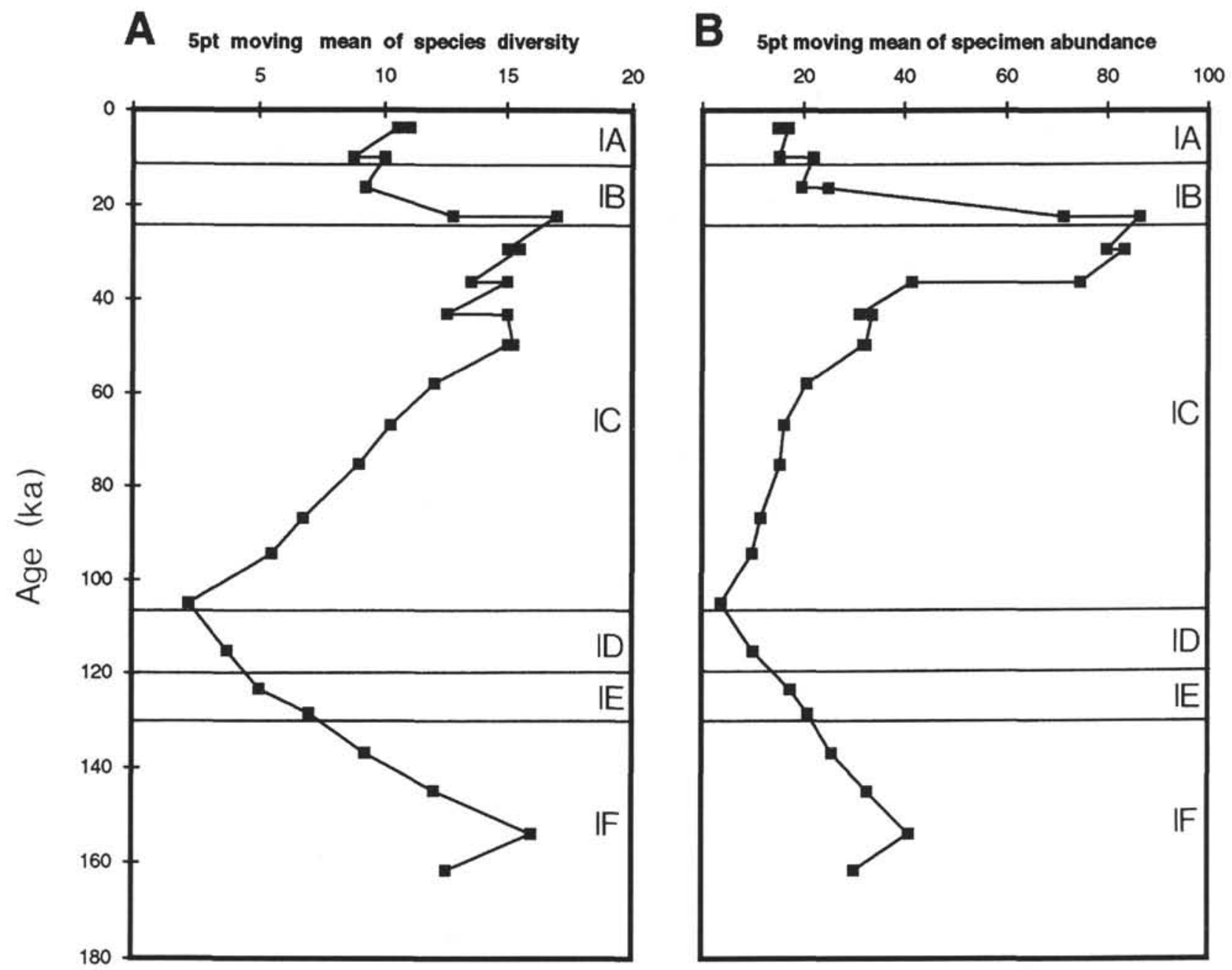

Figure 2. A. Simple species diversity. B. Specimen abundance. Same data and labels as in Figure 1, but plotted as a five-point moving mean vs. age in thousands of years BP.

abundance sampling effect notwithstanding. It is important to note that three broad assemblages can be recognized within the sequence. These cannot be interpreted as true biological assemblages because much of the material is allochthonous, but they can be used to infer regional environmental events. It is also worth pointing out that the boundaries between these three phases correspond well with boundaries between the lithological subunits identified by the Shore-based Scientific Party (1994).

The periods of highest specimen abundance and diversity are correlated with the intermittently laminated sequences (Subunits III and IV), while the lowest abundance and diversity is broadly correlated with the laminated sequences. This latter observation is not unexpected since the laminated sediments are interpreted as being deposited under low oxygen conditions (inimical to the survival of many benthonic organisms). Furthermore, the presence of fine laminae indicates little sedimentary disturbance such as turbidity action. The sustained increase in Ostracoda abundance and diversity during the deposition of Subunit III may be, in part, a biological effect and reflect the recovery of bottom-water oxygen levels, allowing taxa from surrounding regions to recolonize to "pre-kenoxia" levels. The peaks in abundance and diversity at about the last glacial maximum $(\sim 20$ ka) may be attributed to greater downslope transport at this time. Climatic changes at that time may have led to a habitat shift consequent upon the sea level lowering.

\section{CONCLUSIONS}

The Ostracoda assemblages recovered from the late Quaternary marine sequence in the Santa Barbara Basin contain a high percentage of allochthonous specimens transported from shallower depths on the shelf. Faunal changes within the Ostracoda reflect both biological and environmental changes. The faunal similarity with the Alaskan shelf assemblages indicates that elements of the faunas described by Brouwers $(1990,1993)$ either may have a distribution range that extends much further south than thought previously, or this may reflect a faunal shift southward during glacial intervals.

\section{ACKNOWLEDGMENTS}

The authors wish to thank Mr. Gordon Rattray for sample preparation, Mr. Richard Jones for SEM work, and David Griffiths and Geraint Hughes for photography (all at the Institute of Earth Studies, University of Wales, Aberystwyth).

\section{REFERENCES}

Benson, R.H., 1959. Ecology of Recent Ostracodes of the Toodos Santos Bay region, Baja California, Mexico. (Arthropoda, Article 1). Univ. Kans. Paleont. Contrib., 23:1-80. 
Benson, R.H., and Kaesler, R.L., 1963. Recent Marine and lagoonal ostracodes from the Estero de Tastiota Region. Sonora, Mexico (Northeastern Gulf of California). (Arthropoda. Article 3). Univ. Kans. Paleont. Contrib., 23:1-34.

Boomer, I.D., and Whatley, R.C., in press. Cainozoic Ostracoda from guyots in the Western Pacific: Leg 143, Holes 865B and 866B. In Winterer. E.L.. Sager. W.W., Firth. J.V.. and Sinton, J.M. (Eds.), Proc. ODP. Sci. Results, 143: College Station, TX (Ocean Drilling Program).

Brouwers, E.M., 1988. Palaeobathymetry on the continental shelf based on examples using ostracods from the Gulf of Alaska. In De Deckker, P.. Colin J.-P.. and Peypouquet, J.-P. (Eds.), Ostracoda in the Earth Sciences: Amsterdam (Elsevier), 55-76.

Brouwers, E.M.. 1990. Systematic Paleontology of Quaternary Ostracode Assemblages from the Gulf of Alaska, Part 1. Families Cytherellidae, Bairdiidae, Cytheridae, Leptocytheridae, Limnocytheridae, Eucytheridae, Krithidae, Cushmanideidae. Geol. Surv. Prof. Pap. U.S., 1510:143.

Brouwers, E.M., 1993. Systematic Paleontology of Quaternary Ostracode Assemblages from the Gulf of Alaska, Part 2. Families Trachyleberididae. Hemicytheridae, Loxoconchidae, Paracytherideidae. Geol. Surv. Prof. Pap.U.S., 1531:1-47.

Carreño, A.L.. 1992. Neogene microfossils from the Santiago Diatomite. Baja California sur. Mexico. Paleontol. Mex., 59:1-37.

Cronin. T.M.. Brouwers, E.M.. Quinn. H.A.. and Redline. A.. 1983. Ostracodes from the Pico and Santa Barbara Formations, Ventura Basin, California. In Larue. D.K., and Steel. R.J. (Eds.). Cenozoic Marine Sedimentation, Pacific Margin, USA. Pac. Sect., Soc. Econ. Paleontol. Mineral., 205-221.

Finger, K.M., 1982. Biostratigraphy and paleoecology of a new ostracode fauna from the Rincon Formation (Oligo-Miocene), Los Sauces Creek. California. Pac. Sect., AAPG-SEG-SEPM, 57th Annu. Meeting, Anaheim. 43-44. (Abstract)
Finger, K.M., 1983, Ostracoda from the lower Rincon Formation (OligoMiocene) of southern California. Micropaleontology, 29:78-109.

Kennett. J.P., Baldauf, J.G., et al., 1994. Proc. ODP, Init. Repts., 146 (Pt. 2): College Station, TX (Ocean Drilling Program).

LeRoy, L.W., 1943. Pleistocene and Pliocene Ostracoda of the coastal region of southern California. J. Paleontol., 17:354-373.

Shore-based Scientific Party, 1994. Site 893. In Kennett, J.P., Baldauf, J.G. et al., Proc. ODP, Init. Repts., 146 (Pt.2): College Station, TX (Ocean Drilling Program), 15-50.

Swain, F.M., 1969. Taxonomy and ecology of nearshore Ostracoda from the Pacific Coast of North and Central America. In Neale, J.W. (Ed.), The Taxonomy, Morphology and Ecology of Recent Ostracoda: Edinburgh (Oliver \& Boyd), 423-474.

Swain, F.M., and Gilby, J.M., 1974. Marine Holocene Ostracoda from the Pacific Coast of North and Central America. Micropaleontology, $20: 257-474$.

Whatley, R.C., 1983a. Some simple procedures for enhancing the use of Ostracoda in palaeoenvironmental analysis. Norw. Pet. Dir., Bull., 2:129-146.

Whatley, R.C.. 1983b. The application of Ostracoda to palaeoenvironmental analysis. In Maddocks, R.F. (Ed.), Applications of Ostracoda: Houston (Univ. Houston), 51-77.

Whatley, R.C., 1988. Population structure of Ostracods: Some general principles for the recognition of palaeoenvironments. In De Deckker, P., Colin J.-P., and Peypouquet, J.-P. (Eds.), Ostracoda in the Earth Sciences: Amsterdam (Elsevier), 245-256

\section{Date of initial receipt: 24 August 1994 \\ Date of acceptance: 3 January 1995 \\ Ms 146SR-281}

Plate 1. All are adult valves unless otherwise stated. 1. Cytheropteron $\mathrm{sp}$. A. LV. Sample 146-893A-5H-CC, 16-18 cm. $740 \mu \mathrm{m}$ long. 2. Cytheropteron sp. C. RV. Sample 146-893A-7H-CC. $55-58 \mathrm{~cm}, 430 \mu \mathrm{m}$ long. 3, 4, 8. Cytheropteron sp. B. (3) juvenile?. RV. Sample 146-893A-18H-CC, $12-14 \mathrm{~cm}, 340 \mu \mathrm{m}$ long, (4) juvenile?. RV. Sample 146-893A-18H-CC, 12-14 cm, $240 \mu \mathrm{m}$ long. (8) juvenile, LV. Sample 146-893A-5H-CC, 16-18 cm, $310 \mu \mathrm{m}$ long. 5. Semicytherura sp. A. RV. Sample 146-893A-7H-CC, 55-58, $350 \mu \mathrm{m}$ long. 6, 7. Semicytherura sp. B. (6) LV. Sample 146-893A-7H-CC, $28-30 \mathrm{~cm}, 370 \mu \mathrm{m}$ long, (7) juvenile, RV. Sample 146-893A-5H-CC, 16-18 cm, $280 \mu \mathrm{m}$ long. 9. Semicytherura henryi Brouwers, 1995. RV, Sample 146-893A-7H-CC. 55-58 cm, 360 $\mu \mathrm{m}$ long. 10. Semicytherura sp. D. juvenile?, LV. Sample 146-893A-18H-CC, 12-14 cm, $460 \mu \mathrm{m}$ long. 11. Loxocythere? sp. A. juvenile, LV, Sample 146-893A-11H-CC, $26-28 \mathrm{~cm}, 350 \mu \mathrm{m}$ long. 12. Kangarina sp. A. LV. Sample 146-893A-1IH-CC, $26-28 \mathrm{~cm}, 350 \mu \mathrm{m}$ long. 13. Cytheromorpha krausei? (Brouwers, 1993). RV, Sample 146-893A-7H-CC, 55-58 cm, $400 \mu \mathrm{m}$ long. 14. Loxoconcha russellensis (Brouwers, 1993). LV. Sample 146-893A-7H-CC, 55-58 cm, 360 $\mu \mathrm{m}$ long. 15. Cluthia foresteri Brouwers, 1990. LV, Sample 146-893A-5H-CC, 16-18 cm, $360 \mu \mathrm{m}$ long. 16. Palmoconcha sp. B. RV, Sample 146-893A-17H-CC, II-13 $\mathrm{cm}, 550 \mu \mathrm{m}$ long. 17-20. Loxoconchidea dolgoiensis Brouwers, 1990. (19, 20) from Sample 146-893A-5H-CC, 16-18 cm, and (17, 18) from Sample 146$893 \mathrm{~A}-17 \mathrm{H}-\mathrm{CC}, 11-13 \mathrm{~cm}$, (17) LV, female, $340 \mu \mathrm{m}$ long, (18) RV, female, $360 \mu \mathrm{m}$ long, (19) RV, male, $320 \mu \mathrm{m}$ long, (20) RV internal, female, $350 \mu \mathrm{m}$ long. 21-23. Swainocythere chejudoensis Ishizaki, 1981. Sample 146-893A-5H-CC, 16-18 cm. (21) RV, $270 \mu \mathrm{m}$ long, (22) LV, 290 $\mu \mathrm{m}$ long, (23) LV internal, 290 $\mu \mathrm{m}$ long. 24. Krithe adelspergi Brouwers, 1990. RV, Sample 146-893A-17H-CC, $11-13 \mathrm{~cm}, 600 \mu \mathrm{m}$ long. 25. Propontocypris? sp. LV. Sample 146-893A-7HCC, $55-58 \mathrm{~cm}, 400 \mu \mathrm{m}$ long. 26. Puriana? sp. A. juvenile. LV. Sample 146-893A-18H-CC, $12-14 \mathrm{~cm}, 360 \mu \mathrm{m}$ long. 27. Pectocythere janae Brouwers 1990. LV, Sample 146-893A-7H-CC, $28-30 \mathrm{~cm}, 560 \mu \mathrm{m}$ long. 28. Muellerina sp. A. LV. Sample 146-893A-7H-CC, 55-58 cm, $420 \mu \mathrm{m}$ long. 29. Hermanites? sp. A. juvenile, LV, Sample 146-893A-5H-CC. 16-18 cm, $370 \mu \mathrm{m}$ long. 30. Ambostracon sp. A. juvenile, RV, Sample 146-893A-18H-CC, $12-14 \mathrm{~cm}, 270 \mu \mathrm{m}$ long. 31, 32. Ambostracon tweedsmuirensis Brouwers, 1993. (31) juvenile, RV, Sample 146-893A-7H-CC, $28-30 \mathrm{~cm}, 620 \mu \mathrm{m}$ long, (32) juvenile, LV, Sample 146893A-7H-CC. 55-58 cm. $450 \mu \mathrm{m}$ long. 33. Ambostracon sp. B. juvenile, RV, Sample I46-893A-7H-CC, 55-58 cm, $420 \mu \mathrm{m}$ long. 34. Paracytheridea sp. A. juvenile. LV. Sample 146-893A-5H-CC, 16-18 cm, $300 \mu \mathrm{m}$ long. 35. Propontocypris sp. A. RV. Sample 146-893A-7H-CC, 55-58 cm, $350 \mu \mathrm{m}$ long. 36. Sahnicythere sp. A. LV, Sample 146-893A-7H-CC, $55-58 \mathrm{~cm}, 410 \mu \mathrm{m}$ long. 37. Xestoleberis sp. B. RV, Sample 146-893A-5H-CC, 16-18 cm, 250 $\mu \mathrm{m}$ long. 38, 39. Xestoleberis sp. A. Sample 146-893A-5H-CC, 16-18 cm. (38) LV, $240 \mu \mathrm{m}$ long. (39) RV. $250 \mu \mathrm{m}$ long. 40. Pontocythere sp. cf. P. jefferiesensis Brouwers, 1990. LV. Sample 146-893A-7H-CC. $28-30 \mathrm{~cm}, 520 \mu \mathrm{m}$ long. 41, 42. Pontocythere sp. A. Sample 146-893A-7H-CC, $55-58 \mathrm{~cm}$. (41) LV, 260 $\mu \mathrm{m}$ long, (42) RV. $250 \mu \mathrm{m}$ long. 


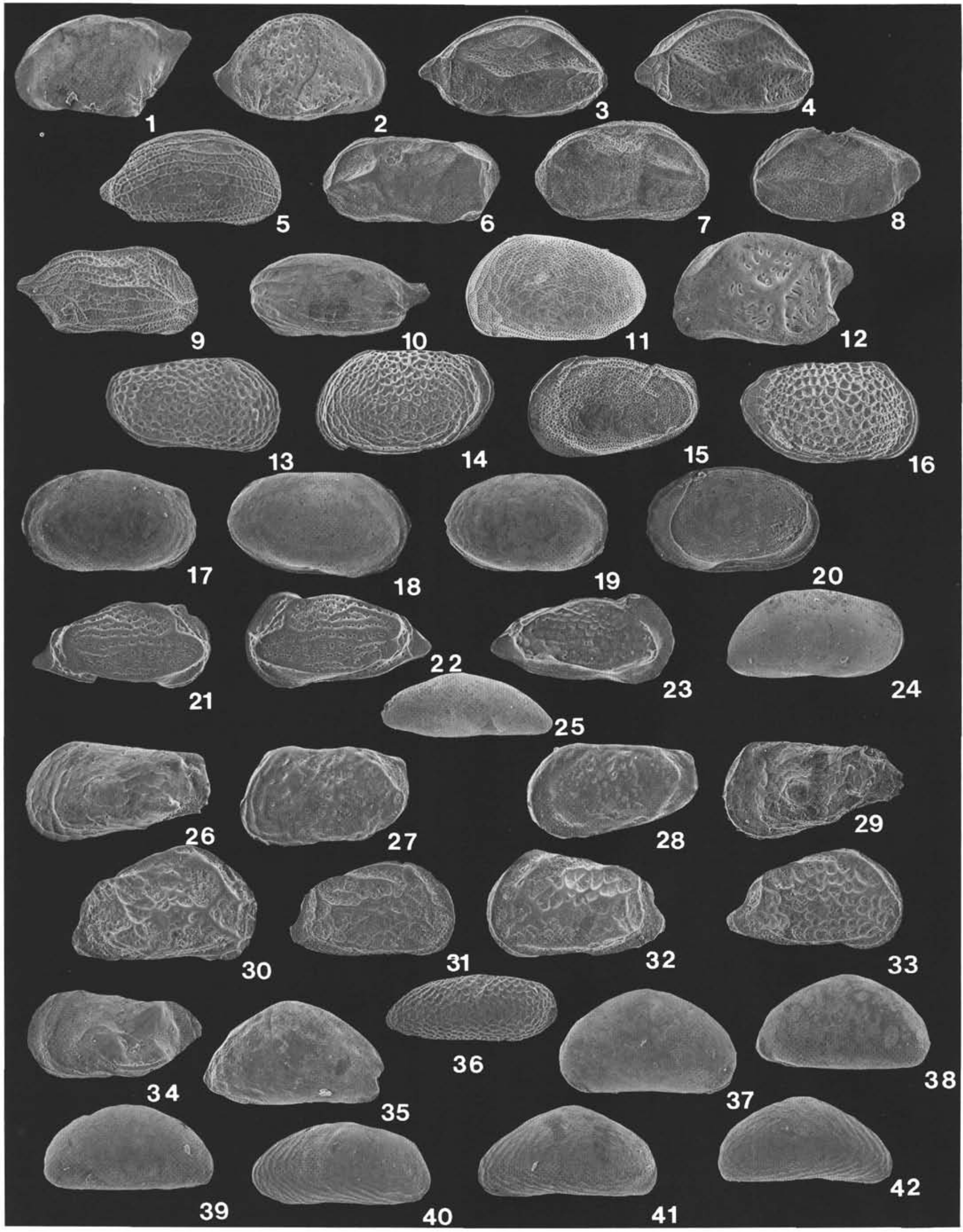

